DOI: https://doi.org/10.24297/jal.v11i.8926

\title{
Empirical Research of Mandarin Popularization Boosting County-level Innovation and Entrepreneurship in Ethnic Minority Regions: Evidences from Eight Counties (Cities) in Guangxi Sino-Vietnam Border
}

\author{
Bian Zhiyao ${ }^{1}$ \\ ${ }^{1}$ Guangxi University of Finance and Economics, Nanning, Guangxi, China, 530003. \\ Bian Zhiyao (February, 1994), male, Yao Nationality, Teacher of news and Cultural Communication in Guangxi \\ University of Finance and Economics, Guangxi, China.
}

260373309@qq.com.

\begin{abstract}
From the perspective of the transaction cost theory, this paper analyzes that the mandarin popularization in ethnic minority regions helps reduce the transaction cost, enhances trust, results in the "innovation and entrepreneurship" effect, and improves the action mechanism of the county-level innovation and entrepreneurship rate. Furthermore, based on the complete sample investigation results of rural residents within $0-3 \mathrm{~km}$ in eight counties of Sino-Vietnam border, it constructs the quantitative model to conduct the empirical analysis of the significant positive role played by mandarin popularization in the county-level innovation and entrepreneurship in ethnic minority regions, which is that when the mandarin level is changed by $1 \%$, the countylevel innovation and entrepreneurship rate is changed by $0.397 \%$.
\end{abstract}

Keywords: Mandarin popularization and county-level innovation and entrepreneurship; Transaction cost theory; Action mechanism; Empirical research

\section{Introduction}

Action Plan of Poverty Alleviation through Mandarin Popularization (2018-2020) (JYY [2018] No. 1) proposed the objective that "by 2020, the newly increased labor force in poor families should all have the communication and application ability with the universal national language. The young and middle-aged labor force in the current poor regions should have the basic communication ability with the mandarin. The local popularization rate of mandarin should be obviously improved. It should primarily have the language environment of communicating in mandarin, and lay the language foundation for improving the 'hematopoiesis' ability." In order to successfully implement the plan, The Guidelines of CPC Central Committee State Council of Winning the Three-year Action Plan of Poverty Alleviation has been published in August of the same year. The mandarin popularization in our country has attained significant achievements in terms of both breadth and depth. More and more people have improved their economic income by learning mandarin, better communicated with the public outside their groups, and better integrated themselves into the social groups. The theoretical studies and empirical results of scholars following the "human capital theory" (Gilles Grenier,1983; Krishna, et al.,1998), "signal theory" (Clarke, et al., 2011), "social identification theory" (Kinder, 2013), "resource-based theory" (West, et al.,2008; Bird, et al., 2014; Frese, et al., 2014), or "critical period hypothesis" (Penfield, et al., 1959; Pallier, 2007; Bylund, et al.,2012) directly or indirectly prove the role of language in people's quality constitution, mental development process, economic and social development. However, in our country, the extreme poverty regions, as the concentrations of ethnic minority regions, are the focus of poverty alleviation. The extreme poverty regions integrate the old revolutionary base areas, minority areas and border areas, with the typical characteristics of "two-high, one-low, one-poor, and three-heavy", namely the high proportion of poor population and poverty incidence, The low per capita disposable income, The poor infrastructure and residence; Heavy poverty alleviation tasks of three types 
of groups, namely the poor population with basic living allowance and five guarantees, the poor population falling into poverty because of illnesses, and the poor elder people. In addition, after the social development of extreme poverty regions, the social civilization remains low; many people don't learn Chinese and don't know the Chinese characters and mandarin. The Sino-Vietnam Border is composed of the "remote, poor and mountainous regions" with teenagers and elder people in our country, which are the weakest places of poverty alleviation in our country. The comprehensive poverty alleviation of rural residents not only is related to the fulfillment of the objective of building a moderately prosperous society in an all-round way, but also remains the guarantee and foundation of national solidary, social harmony and stability in the border regions. Meanwhile, the poverty alleviation through mandarin popularization in these regions also faces contradictions and dilemmas, such as language diversity and unity, mandarin popularization and language protection of ethnic minorities. Therefore, this paper chooses the research object of the rural residents within $0-3 \mathrm{~km}$ in eight counties of SinoVietnam Border in the Guangxi Zhuang Autonomous Region, the province with the most ethnic minorities in our country. The investigation mode is the complete sample investigation. From the perspective of the transaction consumption theory, it analyzes the influence mechanism of influence mandarin popularization on the county-level innovation and entrepreneurship in ethnic minority regions. Based on the investigation result of eight countries in Sino-Vietnam Border from 2017 to 2019, it conducts the model demonstration of mandarin popularization boosting the county-level innovation and entrepreneurship rate in ethnic minority regions, and proposes the suggestions for improving the mandarin popularization in ethnic minority regions.

\section{Theoretical Foundation and Action Mechanism of Mandarin Popularization Boosting County-level Innovation and Entrepreneurship in Ethnic Minority Regions}

\section{(I) The transaction cost theory}

The transaction cost and the transaction expense have the same meaning in English, so it is not distinguished in theoretical research. Transaction cost is the fundamental concept of the new institutional economics, which provides the brand-new perspective and tool for the analysis of economic theory and the explanation of economic phenomenon. The new institutional economics with the transaction cost theory as the center has become the important branch of modern economics. The ancient Greek philosopher Aristotle was the first one that proposed the concept of "transaction". He divided the modes of becoming rich into the natural mode, the transaction mode and the third mode, such as logging and mining. He also divided the transaction into three types, namely the commercial transaction, the financial transaction (or the monetary transaction) and the labor force transaction (or the employment system). The concept of "transaction" is equal to "exchange", namely the bilateral transfer of article and labor service. It is the institutional economist John R. Commons (1934) that brought transaction into the strict economics category. Based on the "production" concept of economics, he proposed the "transaction" concept in the economics aspect: "production" is the relationship between man and the nature and "transaction" is the relationship among people. ${ }^{\circledR} / \mathrm{t}$ is the transfer of ownership. The collection of different concrete transactions is the "operation mechanism" or system. Therefore, in the opinion of Commons, "transaction" is the basic analysis unit of the institutional economics. The non-formal rules like customs, habit and language and formal rules like the constitution may be discussed and analyzed under the concept of "transaction". Meanwhile, Commons divided the transaction activities into three types: bargaining transaction,

\footnotetext{
(1) From the perspective of economics, "transaction" is different from "exchange" in classical economics and neoclassical economics. "Exchange" is a process of transferring and receiving objects. It is a balance or stretching relationship of supply and demand of articles. However, "transaction" takes the property right as the object rather than realistic materials. It is the relationship of transferring and receiving the right of natural objects among people, and it legally transfers the legal control. Details: Hu Leming: Evolution of "Transaction" Category -- From Commons to Williamson, Journal of Shandong University of Finance and Economics, Issue 1, 2001, p. 16-19.
} 
managerial transaction, and rationing transaction. However, the transaction of Commons didn't take the cost into account, which was far from the economic reality.

The first person that proposed the idea of "transaction cost" is Coase, R.H, the founder of new institutional economics. Coase (1937) proposed in the paper The Nature of The Firm mentioned "it is at a cost to use the price mechanism; the most obvious cost is all the costs that discover the relative price". In The Problem of Social Cost, he proposed that "in order to conduct a market transaction, it is necessary to discover with whom people trade and tell them that they are willing to trade and notify the conditions of transaction. They should negotiate, bargain, draw up the contract and implement supervision to ensure that the articles can be performed according to the requirements". In 1969, Arrow, K.J, another winner of Nobel Economics Prize, proposed the word "transaction cost" for the first time when he studied the adverse selection behavior and market operation efficiency of the insurance market. He also clearly defined it as the "operating expense of market mechanism". However, both Coase's "transaction cost" theory and Arrow's "transaction cost" definition cannot be operated.

Since 1970s, there have been more and more studies about the definition of transaction cost. The representative scholars include Williamson, O.E, Dahlman, C.J, North, D.C, Steven N.S.Cheung. In summary, the theories may be divided into the transaction labor division theory, the transaction contract theory, the transaction dimension theory, the system cost theory, and the transaction behavior theory. The transaction labor division theory holds that transaction derives from labor division; the transaction cost refers to the system cost of labor division. Not only the market has the transaction cost. Enterprises also have the transaction cost. ${ }^{\circledR}$ The economic role of enterprises or social organizations is to constitute the owners of several elements into a unit to participate in market exchange, so as to reduce the number of market traders, reduce information asymmetry and finally reduce the transaction expenses. The internal transaction cost of enterprises is equal to the size of the market transaction expense, namely the border of the enterprise scale. North (1981) held that labor division and specialization would lead to the diversity of ideology and further increase the transaction cost. ${ }^{2}$ The relationship of transaction, contract and transaction cost means that all the sections of contract have the transaction cost. Therefore, almost all the institutional economists have analyzed the transaction cost through the contract process. With the contract process as the main line, Dahlman (1979) divided the transaction cost into three parts: before signing, when signing and after signing. The time and resources used by the transaction parties to know about each other, tell the transaction opportunities to each other and achieve the transaction will are the transaction cost before the contract is signed. The cost paid by both parties to determine the transaction conditions is the transaction cost when it is signed. The cost paid by both parties to execute the contract, control and supervise the other party is the transaction cost after it is signed. ${ }^{(8)}$ Williamson (1985) emphasized the importance of the implicit contract, and divided the transaction cost into two parts: the pre-operational and the post-operational. The pre-operational transaction cost includes the drafting, negotiation and maintenance cost of the cooperative contract and agreement. ${ }^{\oplus}$ The post-operational transaction cost includes the maladjustment

\footnotetext{
(1) The internal transaction cost of enterprises includes organization costs like the administration cost, the expense of supervising the founders and the cost of transmitting the administrative orders. Details: R.H.Coase. "The nature of the firm", Economica, Vol.4, 1937, p.386-405.

2) North held that the diversity of ideology comes from the difference of geographical location and occupational specialization, such as the different customs, traditions and languages formed by geographical differences. And the diversity of ideology requires that more resources should be input to contract description and implementation, thus leading to the increase of transaction costs. Details: Douglass C. North. "Structure and change in Economic History", New York, Vol.10, 1986, p.3108-143.

(3) Therefore, according to the opinion of Dahlman, transaction costs include the cost of understanding information, the cost of bargaining and making decisions, and the execution and control cost. Details: Dahlman,C.J. "The problem of externality", Journal of Law and Economics, Vol.22, 1979, p.141-62.

(4) Among them, the "maintenance cost" is very complicated and related to the common ownership, credible commitment and honesty, and the legal verdict of contract dispute. In realistic economic life, the common ownership is the premise of transaction. Credible commitment and honesty are very crucial in the "nonstandard" contract, which contradict with the efficiency and "legal centralism"
} 
cost arising after the transaction deviates from the agreement articles, the bargaining cost arising from both parties' correcting the post-operational inconsistency, the establishment and the operating cost elated to the regulation structure, and the guarantee cost of realizing the credible commitment. When analyzing the spatial boundary of resource allocation, the domestic scholar Sheng Hong (1990) proposed the basic contents of transaction cost, namely the physical power and intelligence (or time) paid in the exchange process, including the distance moved for the exchange, the waiting time, the understanding and inspection of products, and negotiation of the price (the exchange rate) issue. ${ }^{\circledR}$ In order to make the "transaction" more concrete and make the analysis more feasible, Williamson proposed three basic dimensions of transaction on the basis of the bounded rationality and the behavior assumption of opportunism: Transaction frequency, uncertainty degree and assets specificity. ${ }^{2}$ He also analyzed the relationship between the transaction dimension and the transaction cost from the three basic dimensions and the correlation of post-opportunism, governance structure selection and cost reimbursement. The higher the assets specificity is, the higher the potential possibility of the postoperational opportunism behavior is and the higher the market transaction cost is. The higher the transaction frequency is and the stronger the uncertainty is, the higher the transaction cost will be. With Robinson Crusoe's economy as the basis of reference, Steven N.S.Cheung held that the transaction cost includes all the costs ${ }^{\circledR}$ that indirectly arise from the material production process from the broad perspective in 1996. Meanwhile, as the system arises from the transaction cost, Steven N.S.Cheung deemed the transaction cost as a series of system costs, including the information cost, the negotiation cost, the cost of drawing up and executing the contract, the supervision and management cost, and the cost caused by the change of the system structure. On the basis of the "transaction" definition proposed by Commons, Furnbotn and Richer (1997) attributed the transaction cost to all the costs of intercourses among people, including the cost of setting up, using, maintaining and changing the legal systems and the right systems, which may be divided into the market transaction cost, the management transaction cost, and the political transaction cost ${ }^{\oplus}$. Based on Steven N.S.Cheung's understanding that the society with one person cannot have any transaction cost, North (1990) constructed the human behavior theory. The theory divided social behavior into the transaction behavior and the transformation behavior. The transaction behavior includes the purchase of input, the production negotiation process, information acquisition

tradition emphasized by economists in the legal verdict of contract dispute. Details: Williamson,O.E."The economic institutions of capitalism". Journal of Economic Issues. Vol.21, 1985, p.528-530.

(1) On the basis of proposing the contents of the transaction cost, Sheng Hong proposed the concept of the marginal productivity and marginal transaction cost of transaction activities: The marginal productivity of transaction activities is the increment of utility or the saved amount of resources brought by the improved resource allocation efficiency, which is caused by increasing the resource input of one unit to the transaction activity. The reciprocal of the marginal productivity of transaction activities is the marginal transaction cost. Details: Sheng Hong: Market Expansion, Transaction Cost and Production Mode Reform, Management World, Issue 6, 1990, p. 113125.

2. Williamson held that the three basic dimensions are the main dimensions of transaction diversity, among which asset specificity is the most important. Transaction frequency is the times of transaction. Transaction uncertainty includes the uncertainty of happenchance, that of information asymmetry, that of prediction and behavior. However, Williamson emphasized the "uncertainty of behavior", which is the uncertainty caused by strategic concealing, covering or twisting information. Assets specificity means that under the conditions of not sacrificing the production value, assets may be applied to different purposes and used by different people to different degrees. Details: [U.S] Williamson: Transaction Cost Economics: Regulation of Contractual Relationship, published on Enterprise System and Market Organization: Selected Works of Transaction Cost Economics, edited by Chen Xin, Truth \& Wisdom Press, Version 2017 , p. 79 - 104.

(3) Steven N.S.Cheung held: "In the most broad sense, transaction costs include all the costs that cannot exist in the Robinson Crusoe economy with no property right, no transaction and no economic organization, namely all the costs that do not directly occur in the material production process". Details: Steven N.S.Cheung: Economic Organization and Transaction Costs, published on The New Palgrave Dictionary of Economics And the Law, edited by John Eatwell, published by Economic Science Press, 1992, p. 203-256.

(4) The market transaction cost mainly includes the information and negotiation cost; The management transaction cost mainly includes the cost of establishing, maintaining or changing an organization design and the cost of organization operation; The political transaction cost refers to the cost provided by collective action for public goods, including establishing, maintaining or changing the political system. Each type of transaction cost among the three types may be divided into "the fixed transaction cost", namely the investment for system establishment, "the changeable transaction cost", namely the cost depending on the transaction amount or size. Details: [U.S] Erik Furnbotn, [Germany] Rudolph Richer: New Institutional Economics: an Analysis Paradigm of Transaction Cost, translated by Jiang Jianqiang, Luo Changyuan, Shanghai SDX Joint Publishing Company, Version 2006, p. 23 --69. 
and property right protection. The transformation behavior involves the development research of natural materials, the shift and displacement, and the service production. The cost and resources related to the transaction behavior and the transformation behavior are the transaction cost and the transformation costs ${ }^{\mathbb{}}$.

In terms of the concept and connotation of the transaction cost, domestic and foreign scholars also analyzed the influencing factors of the transaction cost, and the quantitative estimation of the transaction cost. Coase held that the transaction cost was the damage to the system efficiency; to reduce the transaction cost was the standard for system (market or enterprise) selection. Williamson attributed the deciding factors of the transaction cost into three aspects: Bounded rationality, opportunism and assets specificity. The domestic scholar Steven N.S.Cheung expanded the transaction cost into the "system cost" and held that the "multiple qualities" of transaction were the key factor deciding the transaction cost. Wu Shanlin (2002) summarized the realistic source of the transaction cost and held that factors like the difference between knowledge and economy, resource rareness, event probability and uncertainty, space limitation, intelligence and language were tightly related to the transaction cost, independently or together leading to the transaction cost. Although some scholars (HellwigM.,1988; Wang Dingding, 1996; Margaret, 2000) held that it was hard to accurately estimate the transaction cost, the academic world still made much pioneering research. The research includes the measure of the total transaction cost in the macro aspect (North and Wallis, 1986; Dollery and Leong, 1998; Van Dalen and Van Vuuren, 2005; Yang Xiaokai, 1988; Jin Yuguo, Zhang Wei, 2004; Zhao Hongjun, 2006; Lu Xianxiang, Li Xiaoping, 2008); and the measure of the transaction cost in the micro aspect (Hernando de Soto, 1989; Colby, 1990; McCann and Easter, 1998; Djankov, La Porta, Lopez-de-Silanes and Shleifer, 2002; Zhou Yan, Pan Yao, 2015, $2017,2019)^{2}$.

Although the concept of the transaction cost is the core and cornerstone of the new institutional economics, there has not been any unified consensus. And there is not any final conclusion of the constitution and measure. These directly influence the realistic explanatory power of the transaction cost theory. However, the realistic sources like the information incompletion and asymmetry, people's difference of knowledge, experience and preference, the "conflict, dependence and order" in transactions decide the existence of the transaction cost; The three basic dimensions of transaction decide the transaction cost; the transaction cost influences people's selection of institutional structure. That the institutional change helps save the transaction cost is the recognized insight and proposition of the new institutional economics; it is also the logic starting point for the new institutional economics to analyze realistic problems.

\section{(II) The action mechanism of mandarin popularization for the county-level innovation and entrepreneurship}

The American linguist William Dwight Whitney (1876) mentioned in the article The Life and Growth of Language: "we regard each language as a system" ${ }^{(3)}$. On the basis of internalizing languages' properties like sociality,

\footnotetext{
(1) North held that both the transformation behavior and the transaction behavior have the "productivity" function; people cannot merely call the transformation cost as the production cost by ignoring the transaction cost. The unrealistic concept that "systems decide on the transaction cost and technology decides on the transformation cost" should be criticized. Both systems and technologies decide on the transaction cost. Details: North, Douglass. C. "Institutions, institutional change, and economic performance". New York: Cambridge University Press.1990a, p.344-405.

(2) The macro research includes the direct measure represented by North and Willis, and the indirect measure by constructing the transaction efficiency index. The micro research is embodied in four aspects: Comparing the transaction costs of managing enterprises in different countries, comparing the exchange cost of the same intermediate commodity transaction in different countries, measuring the transaction cost of a single industry, and measuring the policy-allured transaction cost according to a certain policy. Details: Da Fengyuan, Zhang Weidong: Meaning and Measure of Transaction Cost: Research Overview and Prospect, Research of Institutional Economics, Issue 1, 2010, p. 225-241.

(3) There is no evidence showing how Whitney drew the conclusion that language was an institution, but Whitney is the first one that studied languages as an institution. Details: Zhu Chengquan, Sun Liang: Research of Language Issue from the Perspective of Institutional Economics, Public Administration \& Law, Issue 8, 2013, p. 64-69.
} 
semioticalness and randomicity proposed by Whitney, the Swiss linguist Ferdinand de Saussure (1907) indicated that "language is a symbol system expressing concepts" and held that "language is a pure social system" ${ }^{\circledR}$. On the basis of Saussure's argument of the difference between langue and parole and the linguistic creativity opinion of the father of structural grammar Chomsky, the famous French philosopher and ideologist Maurice Merleau-Ponty (1973) proposed the "dual" properties of language: One is the language after the fact, namely the language as the system. The other one is the language creation of speakers in behavior expression. On the basis of previous studies, the American philosopher J.R.Searle (1979) deeply analyzed the language's institutional property and held that language had the contractual property; individuals couldn't create nor change the language; the language could only exist as the contract that community members jointly adhere to. J.R.Searle further proposed that language was a fundamental social system, for languages not merely described the existing institutional facts; they should also be part of the existing facts. In essence, Searle's opinions are very similar to the conventional language theory ${ }^{2}$. Conventional language theorists regard languages as the conventional rule system. The conventions of people participating in language communication are the necessary and sufficient conditions for the success of the language communication activities. All in all, according to the opinions of disciplines like linguist, philosophy and sociology, language is a social contract influencing the word selection of people in the community and is a fundamental social system. Therefore, it is feasible to study the formation and evolution of language, and study the contractual property and economic function of language from the analytical paradigm and method of institutional economics. It will also strengthen the explanatory power and persuasion of related language issues. As is said by Ariel Rubinstein (2004): "The economic theory is people's attempt of explaining the regularity of people's interaction. And the most basic and non-physical regularity in people's interaction is the natural language. The economic theory carefully analyzes the design of the social system; the language is also a communication mechanism in some sense. Economics tries to explain the social system as the regularity derived from the most optimal process of some functions. It may also be applicable to languages" ${ }^{\text {") }}$.

The new institutional economics holds that the main power of institution evolution is to reduce the transaction cost. Therefore, the reason why languages may reduce the transaction cost and strengthen trust is that languages are a kind of system and the system among systems, namely a "meta" system. Williamson, the representative figure of the new institutional economics attributes the decisive factors of transaction costs to three aspects: Bounded rationality, opportunism and assets specificity. And he decided the transaction cost into the pre-operational and the post-operational. The pre-operational transaction cost includes the drafting, negotiation and maintenance cost of the cooperative contract and agreement. The post-operational transaction cost includes the maladjustment cost arising after the transaction deviates from the agreement articles, the bargaining cost arising from both parties' correcting the post-operational inconsistency, the establishment and the operating cost elated to the regulation structure, and the guarantee cost of realizing the credible commitment. In terms of both the decisive factor and the contents of the transaction cost, language, as a contract and system of communication, plays a direct decisive role in transaction cost. The language is defined

\footnotetext{
1) Saussure held that the reason why languages could be treated as the meta-system or the pure system was that in the language construction process, the connection among sound, thing and concept is arbitrary; however, the expression and inheritance of other social systems depends on certain languages or the restricted selection means. It means that the arbitrary property of languages makes language a meta-system. Details: [Switzerland] Ferdinand de Saussure: Course in General Linguistics, translated by Zhang Shaojie, The Commercial Press, Version 1980, p. 56 - 58.

(2) The research of the American philosopher Lewis D (1983) is representative. He held that some rules can be explained as the stipulations in the groups where they prevail. In languages, a rule can be concretely stipulated as: The stipulation that a possible language L is available to group P is a stipulation of truthfulness and trust in L. Details: Lewis D. "Languages and language". Philosophical Papers, Oxford University Press, 1983.p.24-32.

(3) Rubinstein: Economics and Language, translated by Qian Yong, Zhou Yi, Shanghai University of Finance \& Economics Press, Version 2004, p. 99 - 111.
} 
as a contract or agreement because there are corresponding relationships between sound and meaning of language symbols, syntactic structure and sentence in line with syntax, discourse and verbal behavior. In this aspect, the contract or agreement means that people in the community jointly agree with the above-mentioned corresponding relationship and the restraints of language communication that both parties are willing to accept. It refers to the common rule restricting their verbal behavior when the language users within the community apply the language. Therefore, the conventional language theorists hold that it is the necessary and sufficient condition for the success of language communication to share the same kind of language by the communicators. In order to fulfill the transaction among transaction subjects, both parties or multiple parties are required to use the common language as the carrier in the transaction process to convey information and reach a consensus. Or the secondary language rule ${ }^{\mathbb{1}}$ among communicators must be effectively matched. Otherwise, it will lead to misunderstanding in both parties' communication, and make the transaction hard to achieve. Therefore, to use the common language or the single language in the transaction process plays a direct decisive role in reducing the information asymmetry in the transaction process, enhancing trust, avoiding the opportunism in the transaction process and breaking through the bounded rationality constraints, and further reducing the trading parties' search cost, decreasing the transaction frequency and facilitating the transaction fulfillment, and transaction costs.

The industrial organization theory and development practice fully show that the learning and knowledge communication network formed by the industrial cluster may help strengthen enterprises' innovation ability, and promote the generation and development of new enterprises. It is reputed as the hotbed of cultivating enterprises' learning and innovation ability. The premise for the industrial clusters to form their innovation advantages is that the frequency exchanges and learning formed based on the close space and the same industrial cultural background and language further promote the rapid communication and diffusion of explicit knowledge and implicit knowledge. Therefore, the popularization of mandarin as the official language may reduce the transaction cost among entrepreneurs, strengthen their trust and promote the communication of knowledge and technologies, which further arouses the innovation and entrepreneurship initiative of countylevel rural migrant workers, improve the success rate of innovation and entrepreneurship, and create the "innovation and entrepreneurship" effect. It keeps in line with the conclusions of empirical researches about the relationship between the dialect distance and technology diffusion. Zhao Zile and Lin Jianhao (2017) took the dialect distance as the measure index of cultural difference. Their research found that dialect distance may hinder technology diffusion by influencing trust and communication, and finally influence the balanced development of regional economy. However, with the expansion of the internal migration scale and the mandarin popularization, the effect is obviously declined.

In essence, besides the "innovation and entrepreneurship" effect, the language's communicative function property, language diversity and transaction interaction decide that language distance is a transaction cost and has an important influence on international transaction. The "international transaction" effect of language has already been proved by domestic and foreign empirical research literature (Hutchinson, 2002; Rose, 2004; Ku Hyejin \& Asaf Zussman, 2010; Su Jian, Ge Jiaguo 2013; Guan Xin, Xu Jialu, Qi Xiaofei, 2019) Conclusions agree that language distance and trade flow have the significant negative correlation and its influence on the service

\footnotetext{
(1) "Secondary language rules (systems)" refer to the selection of the secondary rules under an established language system. It refers to the difference of individuals' language expression modes under the established language system. Details: Zhang Weiguo: Language as Human Capital, Public Product and System: A Basic Analysis Framework of Language Economics, Economic Research Journal, Issue 2, 2008, Pag 144 - 154.
} 
trade flow is greater than on the goods' trade flow ${ }^{\mathbb{1}}$. To select the universal language is the effective approach of reducing the transaction cost and promoting transaction.

\section{Empirical analysis of mandarin popularization boosting the county-level innovation and entrepreneurship: Evidences from eight countries in Sino-Vietnam border}

Innovation and entrepreneurship refers to the entrepreneurship activities on the basis of the innovation of one point or several points, such as technical innovation, product innovation, brand innovation, service innovation, commercial mode innovation, management innovation, organizational innovation, market innovation and channel innovation. Innovation is the characteristics of innovation and entrepreneurship; entrepreneurship is the objective of innovation and entrepreneurship. The county-level innovation and entrepreneurship rate refers to the proportion of the number of innovation and entrepreneurship enterprises to the total number of enterprises in a county (district), which means that the county-level innovation and entrepreneurship rate $=$ the number of innovation and entrepreneurship enterprises/the total number of enterprises ${ }^{*} 100 \%$. The mandarin popularization helps expand the "learning effect" among entrepreneurs, reduce the uncertainty in communication and exchange, promote the knowledge and technical communication, and strengthen the initiative and success of innovation and entrepreneurship of migrant workers in cities.

(I) Overview of eight counties in Sino-Vietnam Border

1. Geographical location

Eight counties in Sino-Vietnam Border are connected to the landscape in Vietnam, which enjoy geographical positions. They are the important channels to strengthen the interactions between Guangxi, even China and Vietnam. The details of the geographical locations are shown in Table1.

Table 1 Details of Geographical Locations of Eight Counties in Sino-Vietnam Border

\begin{tabular}{|c|c|c|c|c|}
\hline $\begin{array}{l}\text { City } \\
\text { (District) } \\
\text { County }\end{array}$ & $\begin{array}{l}\text { Neighboring places } \\
\text { in Vietnam }\end{array}$ & Border line & Border port & Administrative area \\
\hline $\begin{array}{l}\text { Dongxing } \\
\text { City }\end{array}$ & $\begin{array}{l}\text { Mong Cai City, Lang } \\
\text { Son Province }\end{array}$ & $\begin{array}{l}\text { The } \\
\text { borderline of } \\
\text { the land area } \\
\text { is } 39 \mathrm{~km} \text { and } \\
\text { the coastline } \\
\text { is } 50 \mathrm{~km}\end{array}$ & $\begin{array}{l}\text { Dongxing Port (national } \\
\text { Type I port), frontier trade } \\
\text { points for inhabitants of } \\
\text { border areas in Yangwu and } \\
\text { Dongxing }\end{array}$ & $\begin{array}{l}\text { It governs } 3 \text { towns, } 31 \\
\text { administrative villages } \\
\text { and } 10 \text { communities. } \\
\text { The regional area is } \\
590 \mathrm{~km}^{2}\end{array}$ \\
\hline $\begin{array}{l}\text { Fangcheng } \\
\text { District }\end{array}$ & $\begin{array}{l}\text { Binh Lieu County in } \\
\text { Quang Ninh } \\
\text { Province }\end{array}$ & $\begin{array}{l}\text { The border } \\
\text { line is over } \\
200 \mathrm{~km}\end{array}$ & $\begin{array}{l}\text { Dongzhong Port (national } \\
\text { Type II port), frontier trade } \\
\text { points for inhabitants of } \\
\text { border areas in Tansan and } \\
\text { Lihuo }\end{array}$ & $\begin{array}{l}\text { It governs } 8 \text { towns, } 2 \\
\text { villages, } 3 \text { streets, } 146 \\
\text { administrative villages } \\
\text { and } 16 \text { communities, } \\
\text { with the area of } \\
2,427 \mathrm{~km}^{2}\end{array}$ \\
\hline
\end{tabular}

(1) The main characteristics of service trade are the intangibility of object products and the complicatedness of bargaining, which decide the important role of languages in service trade. Details: Su Jian: Theoretical Mechanism and Policy Evolution of Language Distance's Influencing International Transaction, Academic Monthly, Issue 12, 2015, p. 59-64. 


\begin{tabular}{|c|c|c|c|c|}
\hline $\begin{array}{l}\text { Ningming } \\
\text { County }\end{array}$ & $\begin{array}{l}\text { Loc Binh County, } \\
\text { Cao Loc County and } \\
\text { Dinh Lap in Lang } \\
\text { Son Province, Binh } \\
\text { Lieu County in } \\
\text { Quang Ninh } \\
\text { Province }\end{array}$ & $\begin{array}{l}\text { Border } \\
\text { length } \\
212 \mathrm{~km}\end{array}$ & $\begin{array}{l}\text { Aidian Port (national Type I } \\
\text { port), frontier trade points } \\
\text { for inhabitants of border } \\
\text { areas in Aidian, Banlan and } \\
\text { Beishan }\end{array}$ & $\begin{array}{l}\text { It governs } 13 \text { towns } \\
\text { (villages), } 3 \text { overseas } \\
\text { Chinese farms, } 162 \\
\text { administrative villages } \\
\text { (communities) and } 1,086 \\
\text { natural villages, with the } \\
\text { area of } 3,705 \mathrm{~km}^{2}\end{array}$ \\
\hline $\begin{array}{l}\text { Pingxiang } \\
\text { City }\end{array}$ & $\begin{array}{l}\text { Lang Son City, Van } \\
\text { Lang County, Cao } \\
\text { Loc County, Trang } \\
\text { Dinh County in Lang } \\
\text { Son Province }\end{array}$ & $\begin{array}{l}\text { Border } \\
\text { length } \\
97 \mathrm{~km}\end{array}$ & $\begin{array}{l}\text { Two national Type I ports, } \\
\text { namely Friendship Pass } \\
\text { (road) and Pingxiang } \\
\text { (railway), one national Type } \\
\text { II port, namely Ping'er Pass } \\
\text { (waterway), frontier trade } \\
\text { points for inhabitants of } \\
\text { border areas including } \\
\text { Nongyao (including Puzhai), } \\
\text { Pingxiang (Jiao'ai), Ping'er } \\
\text { and You'ai }\end{array}$ & $\begin{array}{l}\text { It governs } 4 \text { towns, } 31 \\
\text { villages and } 7 \text { villages, } \\
\text { with the area of } 650 \mathrm{~km}^{2}\end{array}$ \\
\hline $\begin{array}{l}\text { Longzhou } \\
\text { County }\end{array}$ & $\begin{array}{l}\text { Trang Dinh County } \\
\text { in Lang Son } \\
\text { Province, Thach An } \\
\text { County, Ha Lang } \\
\text { County, Trung } \\
\text { Khanh County, } \\
\text { Quang Hoa County } \\
\text { in Cao Bang }\end{array}$ & $\begin{array}{l}\text { Border } \\
\text { length } \\
184 \mathrm{~km}\end{array}$ & $\begin{array}{l}\text { Shuikou is the national Type } \\
\text { I port, and local port } \\
\text { subordinate to Kejia, frontier } \\
\text { trade points for inhabitants } \\
\text { of border areas in Ganmen, } \\
\text { Nahua, Kejia, Shuikou and } \\
\text { Buju }\end{array}$ & $\begin{array}{l}\text { It governs } 12 \text { towns } \\
\text { (villages), } 117 \\
\text { administrative villages } \\
\text { and } 17 \text { communities, } \\
\text { with the area of } \\
2,317.8 \mathrm{~km}^{2}\end{array}$ \\
\hline $\begin{array}{l}\text { Daxin } \\
\text { County }\end{array}$ & $\begin{array}{l}\text { Ha Lang County, } \\
\text { Trung Khanh County } \\
\text { in Cao Bang }\end{array}$ & $\begin{array}{l}\text { Border } \\
\text { length } \\
43 \mathrm{~km}\end{array}$ & $\begin{array}{l}\text { Shuolong Port (national } \\
\text { Type I port), frontier trade } \\
\text { points for inhabitants of } \\
\text { border areas in Yanying, } \\
\text { Shuolong and Detian }\end{array}$ & $\begin{array}{l}\text { It governs } 14 \text { towns } \\
\text { (villages), } 1 \text { overseas } \\
\text { Chinese economic } \\
\text { management area, } 146 \\
\text { administrative villages } \\
\text { (communities) and } 1356 \\
\text { natural villages, with the } \\
\text { area of } 2,742 \mathrm{~km}^{2}\end{array}$ \\
\hline Jingxi City & $\begin{array}{l}\text { Tra Linh County, } \\
\text { Trung Khanh County } \\
\text { in Cao Bang }\end{array}$ & $\begin{array}{l}\text { Border li } \\
\text { length } \\
152.5 \mathrm{~km}\end{array}$ & $\begin{array}{l}\text { Longbang Port (national } \\
\text { Type I port), frontier trade } \\
\text { points for inhabitants of } \\
\text { border areas in Yuewei, } \\
\text { Longbang, Mengma, } \\
\text { Xinxing, etc. }\end{array}$ & $\begin{array}{l}\text { It governs } 11 \text { towns, } 8 \\
\text { villages, } 9 \text { communities, } \\
28 \text { resident communities } \\
\text { and } 254 \quad \text { village } \\
\text { committees, with the } \\
\text { area of } 3,322 \mathrm{~km}^{2}\end{array}$ \\
\hline
\end{tabular}




\begin{tabular}{|c|c|c|c|c|}
\hline $\begin{array}{l}\text { Napo } \\
\text { County }\end{array}$ & $\begin{array}{l}\text { Meo Vac County in } \\
\text { Tinh Ha Giang, Bao } \\
\text { Lac and Ha Quang } \\
\text { County in CaoBang }\end{array}$ & $\begin{array}{l}\text { Border line } \\
\text { length } \\
206.5 \mathrm{~km}\end{array}$ & $\begin{array}{l}\text { Pingmeng Port (national } \\
\text { Type II port), frontier trade } \\
\text { points for inhabitants of } \\
\text { border areas in Bainan, } \\
\text { Pochou, Nongping, } \\
\text { Pingmeng, Nabu and } \\
\text { Nianjing }\end{array}$ & $\begin{array}{l}\text { It governs } 3 \text { towns, } 6 \\
\text { villages, } 3 \text { resident } \\
\text { committees and } 127 \\
\text { village committees, with } \\
\text { the area of } 2,231.11 \mathrm{~km}^{2}\end{array}$ \\
\hline
\end{tabular}

\section{Economic development}

Up to the end of 2018, among the eight counties in Sino-Vietnam Border, Ningming County had the most regional GDP, which was RMB15.43 billion; Napo County had the least regional GDP, which was RMB2.66 billion. The difference of the two counties was RMB12.77 billion. The total regional GDP of the eight counties was RMB90.861 billion (shown in Table2). The one with the most per capita regional GDP was Pingxiang City, which reached RMB75,051. The second one was Dongxing City, which was RMB61,108. The least one is Jingxi City, which was RMB14,833. The per capita regional GDP in eight counties was RMB44,665.88.

Table 2 GDP and Per Capita GDP in Eight Counties in Sino-Vietnam Border in 2018

\begin{tabular}{lllll} 
City (District) County & Regional GDP (RMB100 million) & Ranking & Per capita regional GDP (RMB) & Ranking \\
\hline Dongxing City & 98.29 & 6 & 61108 & 2 \\
Fangcheng District & 139.81 & 3 & 35539 & 6 \\
Ningming County & 154.3 & 1 & 43477 & 5 \\
Pingxiang City & 90.1 & 7 & 75051 & 1 \\
Longzhou County & 129.38 & 4 & 56797 & 3 \\
Daxin County & 141.6 & 2 & 45967 & 8 \\
Jingxi City & 128.53 & 5 & 14833 & 7 \\
Napo County & 26.6 & 8 & 24555 & 8 \\
\hline
\end{tabular}

\section{Language life}

The ethnic minority regions in the border area have various languages, including mandarin, dialect, languages of ethnic minorities and cross-border languages, thus forming the abundant language life. For example, Dongxing City has mandarin, Cantonese dialect, Hakka dialect, Gin language, Cuengh language and Vietnamese. It is quite common for residents in Dongxing City to apply various languages. Most residents may speak more than two languages. They mainly use the local dialect and mandarin, such as Gin language and mandarin, Cantonese dialect and mandarin, Hakka dialect and mandarin. Residents in Jingxi City use eight languages, such as mandarin, the Cantonese, Hakka dialect, Guilin and Liuzhou dialect, Cuengh language, Hmong language, Mian language and Vietnamese. It is also quite common for residents in Jingxi City to apply various languages. Most residents may speak more than two languages. Jingxi City is a typical gathering place of Zhuang nationality, so the Cuengh language and mandarin are commonly used by bilingual residents. Other bilingual languages 
include mandarin and Cantonese dialect, mandarin and Hmong language, mandarin and Vietnamese. Jingxi City has eight types of languages, and a complicated language environment. Therefore, some residents may speak three languages, such as "the Cuengh language - mandarin - the Cantonese dialect", "the Cuengh language mandarin - the Guilin and Liuzhou dialect", "the Cuengh language - mandarin - Vietnamese", "the Cuengh language - the Mian language - mandarin".

\section{(II) Literature review}

As the backflow size of migrant workers is expanded, the academia also conducts quantitative studies of language and entrepreneurship of migrant workers, the influencing factors of the backflow of migrant workers, and occupational selection of migrant workers after they return home. Among the empirical researches of migrant workers' entrepreneurship back at home, the independent variables mainly involve the success rate of migrant workers' entrepreneurship, migrant workers' entrepreneurship will, and migrant workers' entrepreneurship opportunities. The control variables include human capital, social capital, gender, age, occupation, parents' occupation and educational level. The research contents mainly show the relationship between the mandarin skill, the dialect skill and migrant workers' entrepreneurship. Among the empirical researches of migrant workers' innovation and entrepreneurship, the top 5 control variables are shown in Table3.

Table 3 Common Control Variables in the Empirical Researches of the County-level Innovation and Entrepreneurship

\begin{tabular}{|c|c|c|}
\hline Ranking & Control variable & Scholars that adopt the control variables \\
\hline 1 & $\begin{array}{l}\text { Individual characteristic variables, } \\
\text { including gender, age and } \\
\text { marriage }\end{array}$ & $\begin{array}{l}\text { Wei Jifei, 2008; Jiang Jianyong; 2014; Liu Fangfang, 2015; Deng } \\
\text { Daocai, 2015; Wei Xiahai, 2016; Dong Jing, et al., 2019; Tang } \\
\text { Manping, 2019; Deng Xiuzhi, } 2019\end{array}$ \\
\hline 2 & Education background & $\begin{array}{l}\text { Wei Jifei, 2008; Jiang Jianyong; 2014; Deng Daocai, 2015; Dong } \\
\text { Jing, 2019; Yang Hua, 2019; Deng Xiuzhi, } 2019\end{array}$ \\
\hline 3 & $\begin{array}{l}\text { Whether accepting professional } \\
\text { training or not }\end{array}$ & $\begin{array}{l}\text { Wei Jifei, 2008; Liu Fangfang, 2015; Deng Daocai, 2015; Wei } \\
\text { Xiahai, 2016; Dong Jing, 2019; Tang Manping, 2019; }\end{array}$ \\
\hline 4 & Location & $\begin{array}{l}\text { Wei Jifei, 2008; Wei Xiahai, 2016; Dong Jing, 2019; Tang } \\
\text { Manping, 2019; Yang Hua, } 2019\end{array}$ \\
\hline 5 & Household income & $\begin{array}{l}\text { Wei Jifei, 2008; Liu Fangfang, 2015; Wei Xiahai, 2016; Dong Jing, } \\
2019\end{array}$ \\
\hline
\end{tabular}

(III) Empirical analysis of mandarin popularization boosting the county-level innovation and entrepreneurship

1. Data source and description

In order to show that the mandarin popularization in ethnic minority regions plays a positive role in boosting the county-level innovation and entrepreneurship, and analyze the influence of mandarin popularization on the county-level innovation and entrepreneurship rate, the questionnaire from 2017 and 2019 was done in eight counties, including Daxin, Dongxing, Fangchenggang, Jingxi, Ningming, Napo, Longzhou and Pingxiang in the Guangxi border. The questionnaire contents include the name, gender, age, nationality, cultural level, ocupation, mother tongue level, mandarin ability and occupation of residents in the investigated areas. Finally, 329,450 questionnaires were retrieved, including 240,045 valid questionnaires through information check. According to the research demands and methods in related literature, the data were screened. The age of laborers was 
restricted from 18 to $65^{\oplus}$. And the missing values and abnormal values of some variables were deleted. The main variables and data conditions are shown in Table5.

The explanatory variable is the mandarin level; the explained variable is the county-level innovation and entrepreneurship rate; the control variables include the fiscal budget expenditure, road mileage, added value of fixed assets and industrial structure of the counties. The data come from Statistical Yearbook of Guangxi from 2017 to 2018, the county government documents and questionnaires. The data in 2019 come from Statistical Yearbook of Guangxi, Guangxi Information Manual, the county government documents and questionnaires (shown in Table4).

Table 4 Variable Definition and Data Source

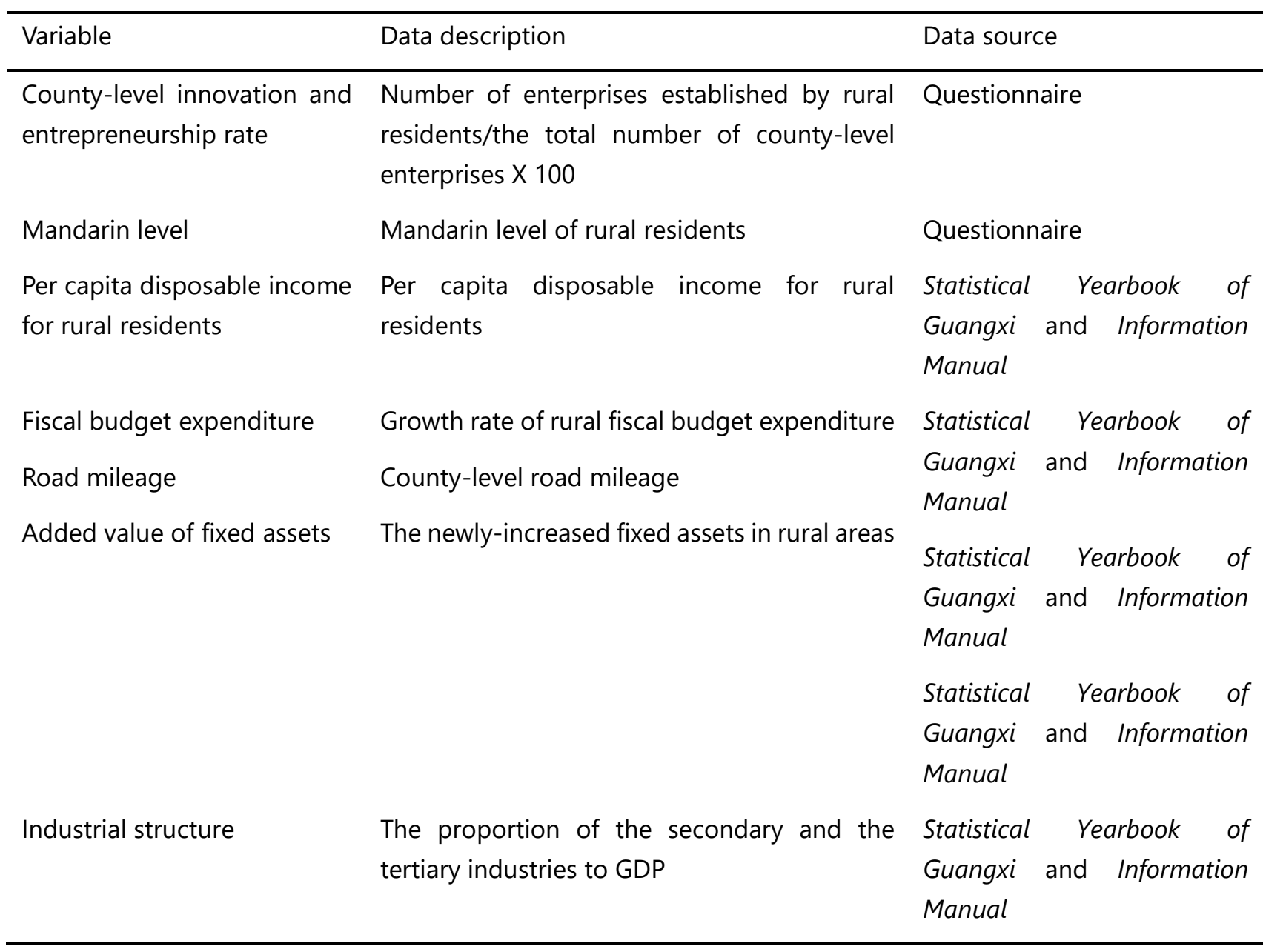

Table 5 Descriptive Statistics of Main Variables

\footnotetext{
(1) In accordance with the General Principles of the Civil Law of the People's Republic of China and Law of the People's Republic of China on the Protection of Minors, a citizen aged 18 or over shall be an adult with full capacity for civil conducts, may independently engage in civil activities and shall be called a person with full capacity for civil conducts. Any organization or individual cannot recruit juveniles under the age of 16 , unless otherwise stipulated by the country. If any organization or individual recruits the juveniles above 16 years old but below 18 years old according to related national stipulations, they shall execute related national stipulations in terms of work type, labor time, labor intensity and protection measures, and shall not arrange them to participate in the labor or dangerous operation that may harm the physical and psychological health of juveniles, such as overweight, poisonous and harmful work. Therefore, in view of the illegal recruitment of child labors and the restrictions of work types and labor intensity of juveniles from 16 to 18 years old, this paper sets the age of research objects above 18 years old. Meanwhile, it sets the age of labor force below 65 years old according to the methods of "China Labor-force Dynamic Survey" (CLDS) and the studies of the domestic scholar Chen Yuanyuan (2016) and other scholars.
} 


\begin{tabular}{|c|c|c|c|c|c|}
\hline Variable & Sample s & eMean Valu & eStandard & nMinil & Maximum \\
\hline Mandarin level & 240045 & 2.191 & 0.661 & 0 & 3 \\
\hline Per capital disposable income of rural residents & s240045 & 1.558 & 1.322 & 0.4 & 30 \\
\hline Gender & 240045 & 0.534 & 0.499 & 0 & 1 \\
\hline Age & 240045 & 40.384 & 11.776 & 18 & 65 \\
\hline Age square & 240045 & 1769.538 & 985.728 & 324 & 4225 \\
\hline Nation & 240045 & 1.737 & 0.668 & 1 & 5 \\
\hline Common language & 240045 & 2.698 & 1.153 & 1 & 8 \\
\hline Educational level & 240045 & 1.775 & 0.727 & 0 & 4 \\
\hline Occupation & 240045 & 1.643 & 0.645 & 1 & 5 \\
\hline
\end{tabular}

\section{Model specification}

In order to study the influence of mandarin popularization on the county-level innovation and entrepreneurship rate, a model is constructed to conduct empirical analysis:

$F E_{i, t}=\lambda_{0}+\lambda_{1}$ Putonghua $_{i, t}+$ ¿controlvars $_{i, t}+\varepsilon_{i, t}$

Among them, $x$ represents the county-level innovation and entrepreneurship rate; i represents the county; and t represents time. $\Sigma F E_{i, t}$ Putonghua $_{i, t}$ The mandarin level of the investigated places is shown. Our country hasn't done any index statistics of mandarin, so the empirical process adopts the questionnaire data from eight counties in Guangxi border from 2017 to 2019. The questionnaire divides the mandarin level into four types, namely "knowing nothing, knowing a little, general, proficient", which are shown through data 0-3. This part averages the mandarin level of knowing a little and above, and thus obtains the county-level mandarin level. controlvars $_{i, t}$ The control variables include the time-delay terms of per capita disposable income of rural residents, industrial structure, growth rate of governmental fiscal expenditure, added value of rural fixed assets, and county-level road mileage. In order to randomize the error terms, $(i=1,2,3 \ldots)$ are the coefficients to be estimated. $\varepsilon_{i, t} \lambda_{i}$ In order to overcome the heteroscedasticity of the model, the logarithmic value is adopted for the variable in the regression analysis process.

\section{Regression result and analysis}

Table6 shows the effect of mandarin popularization on the county-level innovation and entrepreneurship. The result indicates that mandarin popularization plays a significant positive role in promoting the county-level innovation and entrepreneurship. It means that when the mandarin level is changed by $1 \%$, the county-level innovation and entrepreneurship rate will change by $0.397 \%$ and it is significant at the $1 \%$ level. To learn and use mandarin may help reduce the communication cost and frictional cost among laborers, expand the "learning effect" among entrepreneurs, and promote the entrepreneurship activity of workers that go to the town.

Table 6 Regression Result of the Effect of Mandarin Popularization on the County-level Innovation and Entrepreneurship 
Variable

County-level innovation and entrepreneurship

rate

Mandarin level

\section{$0.397^{\star * \star}$}

$(0.0972)$

Time-delay terms of per capita disposable income of rural 0.0511 residents

Industrial structure

Growth rate of governmental fiscal expenditure

Road mileage

Added value of fixed assets

$-0.0724$

Constant term

Sample size

$\mathrm{R}^{2}$

0.746

Notes: ${ }^{*}, * *, * * *$ show the significance level at $10 \%, 5 \%$ and $1 \%$.

4. Stability inspection

In order to ensure the stability of the regression result, the robustness test is done by changing the explanatory variable and the regression method. First of all, in view of the time and individual difference, the regression method is changed from fixed effect into random effect to conduct regression analysis. The regression result is shown in Table7. Second, the explanatory variable, namely the measurement index of mandarin level, is changed. The mandarin level "general, proficient" is averaged as the measurement index of the county-level mandarin level to conduct regression analysis. The result is shown in Table8. The result indicates that to improve the mandarin level plays a significant positive role in improving the county-level innovation and entrepreneurship rate, which is the same with the conclusions obtained in Table6.

Table 7 Robustness Analysis (1)

Variable RE

County-level innovation and entrepreneurship rate 
$(0.163)$

Time-delay terms of per capita disposable income of rural residents

0.0555

$(0.0845)$

Industrial structure

$(0.834)$

Growth rate of governmental fiscal expenditure

$-0.105$

$(0.663)$

Road mileage

$-0.000420$

(0.0412)

Added value of fixed assets

0.158

(0.136)

Constant term

$-2.693$

(2.260)

Sample size

24

$\mathrm{R}^{2}$

0.755

Notes: ${ }^{*}{ }^{* *},{ }^{* * *}$ show the significance level at $10 \%, 5 \%$ and $1 \%$.

Table 8 Robustness Analysis (2)

\begin{tabular}{ll}
\hline Variable & $\begin{array}{l}\text { County-level innovation and entrepreneurship } \\
\text { rate }\end{array}$ \\
\hline Mandarin level & $\begin{array}{l}0.325^{*} \\
(0.168)\end{array}$
\end{tabular}

Time-delay terms of per capita disposable income of rural residents

0.0575

(0.1752)

Industrial structure

Governmental fiscal expenditure

0.505

(0.657)

Road mileage

0.138

(0.133) 
Added value of fixed assets

$-0.0449$

(0.199)

Constant term

Sample size

$\mathrm{R}^{2}$

0.746

Notes: ${ }^{*},{ }^{* *},{ }^{* *}$ show the significance level at $10 \%, 5 \%$ and $1 \%$.

\section{Conclusion}

The regression model is constructed on the basis of the complete sample investigation results of rural residents within $0-3 \mathrm{~km}$ of eight counties in Sino-Vietnam Border, which shows that the mandarin popularization in ethnic minority regions plays a positive role in boosting the county-level innovation and entrepreneurship activities. The regression result shows that mandarin popularization plays a significant positive role in improving the county-level innovation and entrepreneurship rate, which means that when the mandarin level is changed by $1 \%$, the county-level innovation and entrepreneurship rate is changed by $0.397 \%$.

\section{Related suggestions}

The mandarin popularization in ethnic minority regions plays a significant positive role in boosting the countylevel innovation and entrepreneurship, which helps reduce the transaction cost, enhance trust, create the "innovation and entrepreneurship" effect, help win the poverty alleviation battle and boost the new urbanization construction in ethnic minority regions. Therefore, governmental departments should keep adjusting and perfecting the policies of mandarin popularization and accurate poverty alleviation in ethnic minority regions from the perspective of mandarin popularization. The suggestions for improving the mandarin popularization in ethnic minority regions are proposed on the basis of the existing research conclusions and understanding of related policies.

(I) Focus on the improvement and optimization of mandarin popularization degree and structure in ethnic minority regions

The empirical researches show that the innovation and entrepreneurship effect can be created only when the language skill achieves a certain level; and only when the mandarin popularization rate in a region reaches a certain scale can it promote economic development. Therefore, to fulfill the economic effect of poverty alleviation through mandarin popularization not only requires the mandarin popularization rate in a region to reach a certain scale, but also requires individuals' mandarin skills to reach a certain level. It means that while trying to improve the popularization rate of mandarin, attention should also be paid to the popularization degree of mandarin. Up to September 2019, the mandarin popularization rate nationwide was close to $80 \%$; the proportion of literate population using the standard Chinese characters was over 95\%, which basically met the objective proposed by Implementation Plan of Overcoming Project of National Common Language Popularization (JYY (2017) No. 2) ${ }^{\oplus}$. The language barriers for the communication and intercourse in ethnic groups and regions

\footnotetext{
(1) In March 2017, Ministry of Education and State Language Commission jointly printed and issued Implementation Plan of Overcoming Project of National Common Language Popularization (JYY (2017) No. 2), and proposed that "by 2020, the national universal language should be basically popularized nationwide. The concrete national mandarin popularization rate on average should reach over $80 \% "$.
} 
have been basically eliminated. But according to the field investigation results of some scholars, although the mandarin popularization rate is rapidly improved, the mandarin level and quality remain to be improved. Liu Chuqun (2019) investigated the mandarin level of farmers, village cadres and employees of village enterprises living in villages and towns. The results show that only $13.35 \%$ had good mandarin levels; $86.65 \%$ had general mandarin levels; 0 had very good or poor mandarin levels ${ }^{\circledR}$. According to the author's income division standard, those with the income of RMB3,000 and below has the low income; and the corresponding farmers' mandarin level is the "critical value" of labor income effect, which refers to the critical point that mandarin plays a significant boosting role in the labor force income. And the proportion of farmers with the mandarin level higher than the critical value is only $46.08 \%$. Li Xianle, Yang Liping (2019) investigated the language conditions of residents in Xinghua Town in Jiangsu, which showed that the 50\% residents in Xinghua Town had the mandarin level of basic conversation and below. And migrant workers had poor recognition and writing ability of Chinese characters. Their proficient degree was between "not that proficient" and "general"?. Bian Chenglin, Liu Jinlin (2019) investigated farmers in the border area of Jingxi City, Guangxi and the results show that although the mandarin popularization rate of border farmers reached $97 \%$, less than $46 \%$ were proficient with mandarin. Tang Mi (2019) investigated the use conditions of national universal language of Uyghur nationality in the northern Xinjiang area and the results show that among the investigated objects, $85.03 \%$ mastered mandarin; $85.20 \%$ had bilingual ability; $14.97 \%$ only spoke the Uygur language or mandarin. But their overall mandarin level was between "can basically talk with the language but not that proficient" and "proficiently use it but the accent is strong" ${ }^{3}$.

Meanwhile, although the average mandarin popularization rate in our country has been over $80 \%$, the development between the east and the west, the city and the town is uneven. The difference of the mandarin popularization rate between the east and the west is $20 \%$. The popularization rate in big cities has been more than $80 \%$. However, the popularization rate of the rural areas in some ethnic minorities is still around $50 \%$. Some young and middle-aged farmers and herdsmen in some extreme poverty regions even cannot have basic communications with mandarin. It has become the important factor that hinders farmers to get rid of poverty and become better off, restricts our country to comprehensively build a moderately prosperous society in an all-round way, and influences national unity and stability. Zhu Xialin (2019) investigated the mandarin application ability of Wa nationality in Yunnan and the result showed that $78.8 \%$ residents of Wa nationality couldn't speak mandarin in a standard way, among which $32.9 \%$ knew little about mandarin. 28.2\% residents could answer questions with simple words and keywords. 32.9\% couldn't answer with mandarin. Their oral ability of mandarin was very poor. ${ }^{\circledR}$

\footnotetext{
(1) The author's investigated objects do not include teachers and students, urban residents of counties and above. The age of the objects is between 15 and 60. They are young and middle-aged people. The number of questionnaires distributed is 3,000, and the number of recovered valid questionnaires is 2,153 . It divides the mandarin level into five levels: very good, good, general, poor, unable. Details: Liu Chuqun: Correlation Investigation of Laborers' Income and National Universal Language Cognition, Application of Language, Issue 4, 2019, p. 82-91.

(2) The author divides the mandarin ability of investigated objects into five types: proficiently talk, basically talk, say some common words, basically fail to talk, cannot talk at all. It divides the recognition and writing ability of mandarin Chinese characters into five levels: very proficient, proficient, general, not that proficient, not proficient at all. Details: Yang Liping: Investigation of Town Language Conditions in New Urbanization Process -- With Xinghua in Jiangsu as the Example, Master's Dissertation in Yangzhou University, 2019 , p. 18-19.

(3) Through the way of step sampling, the author selects the Uyghur nationality in the Urumqi-Changii area, Turpan area, Hami area, Altay area and Yili area in the northern Xinjiang as the objects, and divides the mandarin level into seven degrees: be able to use mandarin, fluently and accurately use mandarin, fluently use but have some inaccurate pronunciations, proficiently use but have a strong accent, basically talk but not that proficient, be able to understand but cannot speak, cannot understand nor speak. Details: Tang Mi: Investigation of Use Conditions of National Universal Language of Ethnic Minorities in Northern Xinjiang -- With the Example of Uyghur, Journal of Kaifeng Institute of Education, Issue 12, 2019, p. 56-57.

(4) The author divides the mandarin ability of investigated objects into five levels: very standard, standard, not that standard, not standard, unknown. Details: Zhu Xialin: Research of Mandarin Application Ability and Improvement of Wa Nationality in Yunnan from the
} 
The quality of mandarin popularization in our country remains to be improved. And there is the regional, national, urban and rural gap of the popularization rate. Implementation Plan of Overcoming Project of National Common Language Popularization (JYY (2017) No. 2) proposed the key tasks for the east area, the central area and the west area: the east area should mainly improve the level; the central area should mainly reach the standard of popularization; the west area should mainly overcome difficulties of popularization. It also divided the mandarin popularization rate in our country to three levels: counties with the popularization rate of over $70 \%$ and above, counties with the popularization rate of over $50 \%$ and above, and counties with the popularization rate of below $50 \%$. It also formulated the grade objectives of "concentrated improvement", "popularization difficultyovercoming" and "acceleration of minimum guarantee" ${ }^{\text {. }}$.

(II) Cultivate the multilingual ability of border residents in ethnic minority regions, and provide language support for carrying out border trade

Border trade is the exclusive economic trade situation along the borderline of bordering countries. It is also the rudiment of the current international trade. Influenced by geographical factors, cultures and languages in the border areas of ethnic minorities are diversified. However, out of the geographical advantages, border areas and peripheral countries have similar or the same cultures and customs, and languages, thus providing unique conditions for the all-round opening up and cooperation, and border trade of both parties. And foreign languages play the role of bilateral "interconnection" in border trade practice. Therefore, if border residents are proficient with languages in border countries, namely foreign languages, while mastering mandarin and the mother tongue, it will provide language support for their participation in border business or employment in cross-border enterprises. Five counties, including Nyalam and Keelung in the Shigatse Prefecture in the Tibet Autonomous Region, which is at the frontier position of the southwest border of the motherland, and Burang County in Ngari area border on Nepal. The borderline is $1,753 \mathrm{~km}$, almost half of the borderlines close to the Tibet Autonomous Region. It has been the important portal for the friendly intercourse between Tibet and the mainland of our country and South Asian countries. Guangxi Zhuang Autonomous Region, which is at the south gate of the motherland, has 8 counties, cities and districts and 103 towns that adjoin Vietnam. It has the land borderline of $1,020 \mathrm{~km}$. The residents in the Sino-Vietnam Border have frequent intercourses and border trades; the border trade industry develops rapidly. The investigation of border residents in Dongxing City and Jingxi City in Guangxi finds that although the proportion of border residents mastering the cross-border languages, namely Gin language or foreign language --Vietnamese, remains low, the income of those engaged in border trade or Vietnam-invested enterprises is higher than those engaged in agriculture and even general migrant workers. It fully shows that the essential conditions for border residents to exert the locational advantages in border areas and participate in border trade include: to proficiently master the cross-border languages or the language skills of neighboring countries, and have multilingual abilities.

\section{References}

Dahlman, C. J. (1979). The problem of externality. Journal of Law and Economics, Vol.22, p.141 62.

Douglass C. North. (1986). Structure and change in Economic History. New York, Vol.10, p.3108 143.

Perspective of Language Communication, Master's Dissertation in Yunnan Normal University, 2019, p. 23.

(1) Implementation Plan of Overcoming Project of National Common Language Popularization (JYY (2017) No. 2) proposed that concentrated improvement should be done to counties with the popularization rate of $70 \%$ and above, among which $75-79.9 \%$ counties should try to improve it to $80 \%$ before the end of 2018 , and $70-74.9 \%$ counties should try to improve it to $80 \%$ before the end of 2019 . Overcome the difficulties of mandarin popularization in counties with the popularization rate of over $50 \%$ and try to make the popularization rate in over half of the counties reach $70 \%$ by the end of 2020 , among which urban areas should reach the popularization rate of $80 \%$ / Speed up the work in counties with the popularization rate of below $50 \%$ and ensure to improve the counties' popularization rate to over $10 \%$ before the end of 2020 . In principle, the popularization in all the counties should be improved to $50 \%$ and above. 
Lewis D. (1983). Languages and language. Philosophical Papers, Oxford University Press.p.24 32.

North, Douglass. C. (1990). Institutions, institutional change, and economic performance.. New York: Cambridge University Press.p.344 405.

R.H. Coase. (1937). The nature of the firm. Economical, Vol.4, p.386 405.

Williamson, O.E. (1985). The economic institutions of capitalism. Journal of Economic Issues. Vol.21, p.528 530.

Erik Furnbotn \& Rudolph Richer. (2006).New Institutional Economics: an Analysis Paradigm of Transaction Cost, translated by Jiang Jianqiang, Luo Changyuan, Shanghai SDX Joint Publishing Company, p. 23 --69.

Ferdinand de Saussure. (1980). Course in General Linguistics, translated by Zhang Shaojie. The Commercial Press, p. 56 - 58.

Rubinstein. (2004). Economics and language, translated by Qian Yong, Zhou Yi. Shanghai University of Finance \& Economics Press, p. 99 - 111.

Williamson. (2017). Transaction Cost Economics: Regulation of Contractual Relationship. published on Enterprise System and Market Organization: Selected Works of Transaction Cost Economics, edited by Chen Xin, Truth \& Wisdom Press, p. 79 - 104.

Da Fengyuan \& Zhang Weidong. (2010). Meaning and Measure of Transaction Cost: Research Overview and Prospect. Research of Institutional Economics, Issue 1, p. 225-241.

Hu Leming. (2001). Evolution of "Transaction" Category -- From Commons to Williamson. Journal of Shandong University of Finance and Economics, Issue 1, p. 16-19.

Liu Chuqun. (2019). Correlation Investigation of Laborers' Income and National Universal Language Cognition, Application of Language, Issue 4, p. 82-91.

Su Jian. (2015). Theoretical Mechanism and Policy Evolution of Language Distance's Influencing International Transaction. Academic Monthly, Issue 12, 2015, p. 59-64.

Sheng Hong. (1990).Market Expansion, Transaction Cost and Production Mode Reform. Management World, Issue 6, 1990, p. 113-125.

Tang Mi.(2019). Investigation of Use Conditions of National Universal Language of Ethnic Minorities in Northern Xinjiang -- With the Example of Uyghur. Journal of Kaifeng Institute of Education, Issue 12, 2019, p. 56-57.

Yang Liping. (2019).Investigation of Town Language Conditions in New Urbanization Process -- With Xinghua in Jiangsu as the Example. Master's Dissertation in Yangzhou University, p. 18-19.

Zhu Xialin. (2019). Research of Mandarin Application Ability and Improvement of Wa Nationality in Yunnan from the Perspective of Language Communication. Master's Dissertation in Yunnan Normal University, p. 23.

Zhang Weiguo. (2008).Language as Human Capital, Public Product and System: A Basic Analysis Framework of Language Economics. Economic Research Journal, Issue 2, P 144 - 154.

Zhu Chengquan \& Sun Liang.(2013). Research of Language Issue from the Perspective of Institutional Economics. Public Administration \& Law, Issue 8, p. 64-69.

Steven N. S. Cheung. (1992).Economic Organization and Transaction Costs. Economic Science Press, p. 203-256. 